Original Article

\title{
Characterization of glutamine synthetase from the ammonium-excreting strain HM053 of Azospirillum brasilense
}

\author{
Caracterização da glutamina sintetase da estipe excretora de amônio HM053 de \\ Azospirillum brasilense
}

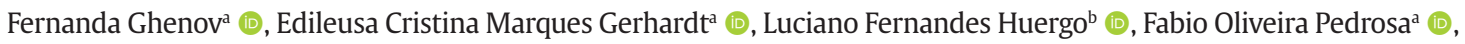 \\ Roseli Wassemc (D) and Emanuel Maltempi Souza ${ }^{a^{*}}$ (D) \\ aUniversidade Federal do Paraná - UFPR, Departamento de Bioquímica e Biologia Molecular, Núcleo de Fixação Biológica de Nitrogênio, \\ Curitiba, PR, Brasil \\ bUniversidade Federal do Paraná - UFPR, Setor Litoral, Caiobá Matinhos, PR, Brasil \\ 'Universidade Federal do Paraná - UFPR, Departamento de Genética, Curitiba, PR, Brasil
}

\begin{abstract}
Glutamine synthetase (GS), encoded by glnA, catalyzes the conversion of L-glutamate and ammonium to L-glutamine. This ATP hydrolysis driven process is the main nitrogen assimilation pathway in the nitrogen-fixing bacterium Azospirillum brasilense. The A. brasilense strain HM053 has poor GS activity and leaks ammonium into the medium under nitrogen fixing conditions. In this work, the $\ln A$ genes of the wild type and HM053 strains were cloned into pET28a, sequenced and overexpressed in E. coli. The GS enzyme was purified by affinity chromatography and characterized. The GS of HM053 strain carries a P347L substitution, which results in low enzyme activity and rendered the enzyme insensitive to adenylylation by the adenilyltransferase GlnE.
\end{abstract}

Keywords: nitrogen fixation, adenylylation, adenilyltransferase, EC 6.3.1.2, GlnE.

\begin{abstract}
Resumo
A glutamina sintetase (GS), codificada por $g \ln A$, catalisa a conversão de L-glutamato e amônio em L-glutamina. Este processo dependente da hidrólise de ATP é a principal via de assimilação de nitrogênio na bactéria fixadora de nitrogênio Azospirillum brasilense. A estirpe HM053 de A. brasilense possui baixa atividade GS e excreta amônio no meio sob condições de fixação de nitrogênio. Neste trabalho, os genes glnA das estirpes do tipo selvagem e HM053 foram clonados em pET28a, sequenciados e superexpressos em $E$. coli. A enzima GS foi purificada por cromatografia de afinidade e caracterizada. A GS da estirpe HM053 possui uma substituição P347L que resulta em baixa atividade enzimática e torna a enzima insensível à adenililação pela adenililtransferase GlnE.
\end{abstract}

Palavras-chave: fixação de nitrogênio, adenililação, adenililtransferase, EC 6.3.1.2, GlnE.

\section{Introduction}

In plants, nitrogen starvation is associated with reduction of cell division and expansion, leaf area and photosynthesis (Lawlor David, 2002). Plants can use as nitrogen sources ammonium, nitrate and amino acids, but cannot incorporate the most abundant form of nitrogen available on earth, dinitrogen $\left(\mathrm{N}_{2}\right)$. Thus, agricultural productivity is heavily dependent of the use of synthetic nitrogen fertilizers, which are expensive and causes severe environment impacts (Ter Steege et al., 2001; Vance, 2001).

Biological fixation of nitrogen is the reduction of dinitrogen gas into ammonium by the nitrogenase complex present in a restricted group of prokaryotes. Amongst other factors, biological nitrogen fixation is negatively controlled by the availability of ammonium (Hartmann et al., 1986; Merrick and Edwards, 1995). Proteobacteria typically assimilate the ammonium through the GS-GOGAT pathway. The glutamine synthetase (GS), encoded by the glnA gene, catalyse the conversion of L-glutamate and ammonium to L-glutamine, in a process energetically driven by ATP hydrolysis (Westby et al., 1987). The glutamate synthase enzyme (GOGAT), encoded by the gltD and gltB genes, catalyse the reductive transfer of the amide group from L-glutamine to $\alpha$-ketoglutarate, producing two L-glutamate molecules in an NADPH-dependent reaction (Merrick and Edwards, 1995; Westby et al., 1987).

Ammonium assimilation requires cellular energy and is regulated at both the transcriptional and post-translational levels. Transcriptional regulation of $g \ln A$ expression is central to the control of ammonia assimilation (Antonyuk, 2007; Dixon and Kahn, 2004; Leigh and Dodsworth,

*e-mail: souzaem@ufpr.br

Received: April 1, 2020 - Accepted: July 29, 2020

This is an Open Access article distributed under the terms of the Creative Commons Attribution License, which permits unrestricted use, distribution, and reproduction in any medium, provided the original work is properly cited. 
2007; Merrick and Edwards, 1995) and modulation of $\operatorname{gln} A$ expression is influenced by the nitrogen state of the cell. The two-component signal transduction system $\mathrm{NtrC} / \mathrm{NtrB}$ controls transcription of $g \ln A$ in A. brasilense (de Zamaroczy et al., 1996). The histidine kinase sensory protein (NtrB) phosphorylates and dephosphorylates the NtrC response regulator in response to the levels of ammonium, leading to the activation or deactivation of NtrC, respectively. Phosphorylated NtrC activates transcription from promoters that are recognized by the RNA polymerase containing the $\sigma^{\mathrm{N}}$ factor and the NtrC binding site (Huergo et al., 2003). In A. brasilense, the $g \ln A$ gene is located downstream of $g \ln B$ and is expressed from a NtrC-dependent promoter and from a secondary intergenic promoter (Van Dommelen et al., 2003; Huergo et al., 2003; Leigh and Dodsworth, 2007).

The GS of $A$. brasilense is regulated post-translationally by reversible adenylylation of its subunits; each monomer of the enzyme can be modified by the attachment of an AMP residue to a conserved tyrosine residue (398) (Bespalova et al., 1994; Pirola et al., 1992). As the enzyme is a dodecamer, adenylylation ranges from 0 to 12 modifications per functional dodecamer (Pirola et al., 1992). The adenylylation process is well described for $E$. coli (Leigh and Dodsworth, 2007; Mangum et al., 1973; Merrick and Edwards, 1995) involving three proteins. The first is the bifunctional adenylyl transferase / adenylyl removing enzyme (ATase or $\mathrm{G} \ln E$ ), a product of the $g \ln E$ gene. This enzyme transfer AMP from ATP to the GS Y398 residue of a subunit of the dodecameric GS. This ATase can also catalyse the AMP removal from GS. The prevailing ATase activity is dictated by the nitrogen availability through interaction with the $G \ln B$, product of the $g \ln B$ gene. $G \ln B$ exists in two forms: unmodified (GlnB), which stimulates GS adenylylation by the ATase; and in the uridylylated form (GlnB-UMP), which stimulates the GS deadenylylation. The third protein, the UTase (product of the $\ln D$ gene), promotes the reversible uridylylation of GlnB. The UTase/ deuridylylating enzyme controls the post-translational modification of GlnB by promoting the deuridylylation of GInB-UMP when the glutamine levels increase under high ammonium availability, stimulating the adenylylation of GS (Araújo et al., 2008; Leigh and Dodsworth, 2007; Merrick and Edwards, 1995). The GlnB paralogue, named GlnK in E. coli and $\mathrm{GlnZ}$ in A. brasilense, undergoes a similar cycle of modification by the UTase, but has distinct cell targets. In A. brasilense, GlnB in addition of controlling the ATase activity also controls the NifA transcriptional activator (Sotomaior et al., 2012) and the inactivation of nitrogenase by ADP-ribosylation (Moure et al., 2014) whereas GlnZ controls the reactivation of nitrogenase by the removal of the ADP-ribosyl moiety (Moure et al., 2014).

A. brasilense is a nitrogen-fixing, plant-growth promoting bacterium that is used as an inoculant to improve productivity of crops such as maize and wheat (Hungria et al., 2010). In nature, this rhizo-bacterium colonizes roots of economically important grasses, including rice, corn, wheat, as well as diverse forages. Plants inoculated with $A$. brasilense possess more robust rooting systems, requiring less input of fertilizers and increasing productivity (Bashan and Holguin, 1997; CamiliosNeto et al., 2014; Dobbelaere et al., 2001; Hungria et al., 2010; Steenhoudt and Vanderleyden, 2000). About 9.1 million doses of $A$. brasilense inoculant were used on maize and wheat in Brazil in 2018 (ANPII, 2018).

Although inoculation with $A$. brasilense leads to gains in productivity, the amount of $\mathrm{N}$ transferred to the plant is limited to about 10\% (Pankievicz et al., 2015). Machado et al. (1991) isolated spontaneous 4 mutants of A. brasilense FP2 (Sp7 ATCC 29145, Sm ${ }^{\mathrm{R}}$, Nal ${ }^{\mathrm{R}}$ ) (Pedrosa and Yates, 1984) that survived treatment with ethylenediamine. These mutants were able to fix nitrogen constitutively $\left(\mathrm{Nif}^{\mathrm{c}}\right)$, even in the presence of high concentrations of ammonium and were able to excrete some of the fixed ammonium to the culture medium; these mutant strains have been characterized genetically and biochemically (Machado et al., 1991; Ishida et al., 2002; Vitorino et al., 2001).

The ability to secrete ammonium is an ideal attribute for biofertilizers. Pankievicz et al. (2015) showed that the Nif ${ }^{\mathrm{C}}$ strain HM053 isolated by Machado et al. (1991) was able to provide $100 \%$ of Setaria viridis nitrogen needs. The same strain was more efficient than the wild type to stimulate growth of wheat (Santos et al., 2017). The strain HM053 has low GS activity (Machado et al., 1991) which was later shown to be caused by a point mutation (cytosine to thymine at position 1040) (Hauer, 2012) in glnA leading to substitution of the proline residue at position 347 for a leucine (P347L). Here we characterized the GS of strain HM053 and compared it to the wild type.

\section{Materials and Methods}

\subsection{Bacteria and growth conditions}

E. coli cells were grown at $37^{\circ} \mathrm{C}$ in liquid LB (Sambrook et al., 1989) with shaking at $120 \mathrm{rpm}$ or in LA solid medium (15 g.L-1 agar) with appropriate antibiotics.

\subsection{Cloning}

The glnA gene of $A$. brasilense FP2 (wild type) and HM053 were amplified using the primers shown in Table S1. The PCR products were cloned into the vector pBluescript II KS (+), digested with EcoRV and the inserts completely sequenced. The $g \ln A$ genes were then transferred to the pET28a vector using the restriction enzymes NdeI and HindIII. The pET28a derivatives were used to express the wild type and mutant (herein named P347L-GS) glutamine synthases of $A$. brasilense in E. coli BL21גDE3.

\subsection{Purification of glutamine synthetase}

E. coli BL21 containing the overexpression plasmids were grown overnight in $6 \mathrm{ml}$ of LB medium containing kanamycin at $37^{\circ} \mathrm{C}$ and $160 \mathrm{rpm}$. This pre-inoculum was then poured into $100 \mathrm{ml}$ of LB containing the antibiotic and shaken at $37^{\circ} \mathrm{C}$ until an optical density of $0.5_{600 \mathrm{~nm}}$ had been reached. Then, to induce protein synthesis $250 \mu \mathrm{M}$ IPTG was added followed by incubation overnight at $16^{\circ} \mathrm{C}$ aerobically. The next day, the cultures were placed on ice for $30 \mathrm{~min}$, then collected by centrifugation $\left(15 \mathrm{~min}, 5000 \mathrm{~g}, 4^{\circ} \mathrm{C}\right)$ and re-suspended in $20 \mathrm{ml}$ of lysis buffer $(150 \mathrm{mM} \mathrm{NaCl}$ and $50 \mathrm{mM}$ Tris- $\mathrm{HCl}, \mathrm{pH} 8$ ). Cells were lysed by sonication in an ice bath (15 cycles, $15 \mathrm{sec}$ on/15 sec off). Lysed cells were centrifuged $\left(30 \mathrm{~min}, 30.000 \mathrm{~g}, 4^{\circ} \mathrm{C}\right)$ and the soluble fraction were purified by $\mathrm{Ni}^{2+}$ affinity chromatography with HiTrap ${ }^{\mathrm{TM}}$ Chelating HP $1 \mathrm{ml}$ columns (GE Healthcare 
Bio-Sciences, Pittsburgh, PA 15264-3065, USA) coupled to a peristaltic pumping system. The proteins were eluted in buffer ( $50 \mathrm{mM}$ Tris- $\mathrm{HCl}, \mathrm{pH} 8,150 \mathrm{mM} \mathrm{NaCl}$ ) with increasing gradient of imidazole from $10 \mathrm{mM}$ to $1 \mathrm{M}$. Purified proteins were quantified by the Bradford method (Bradford, 1976) and the purity was checked on SDS-PAGE gels using the Image program.

\subsection{Identification of glutamine synthetase by MALDI-TOF mass spectroscopy}

Samples were prepared for analysis according to Shevchenko et al. (1996) and analyzed in a MALDI-TOF Autoflex II spectrometer (Bruker Daltonik GmbH, Life Sciences, 28359 Bremen, Germany). Lists of peaks were created using FlexAnalysis 3.0 software (Bruker Daltonik). Protein identification was performed using the Mascot 2.2 software and the protein database of $A$. brasilense sp245 (Wisniewski-dyé et al., 2011).

\subsection{Electrophoresis and western blot assays}

Electrophoresis and western blot assays were performed according to Huergo et al. (2006), with an anti-GS antibody diluted 10,000 fold (van Heeswijk et al., 1996).

\subsection{Transferase activity of glutamine synthetase}

Transferase activity was assayed according to Bender et al. (1977), with some modifications. HEPES 100 $\mathrm{mM}$ was used instead of imidazole hydrochloride and the total reaction volume was reduced to $302.5 \mu \mathrm{l}(10 \mu \mathrm{l}$ sample, $80 \mu \mathrm{lmix}, 12.5 \mu \mathrm{l} \mathrm{L-glutamine} \mathrm{and} 200 \mu \mathrm{l}$ stop mix).

To determine the physiologically active (non-adenylylated) fraction of GS, the system was supplemented with $60 \mathrm{mM}$ $\mathrm{MgCl}_{2}$ which inhibits the adenylylated fraction (physiologically inactive). A pH (7.66) was assumed for the iso-electric point of both the adenylylated and unadenylylated forms (Machado et al., 1991).

\subsection{Phosphodiesterase treatment}

The GS used in Western Blot assays was treated with commercial snake venom phosphodiesterase (Merck) according to Pirola et al. (1992), with some modifications. The reactions containing GS $(0.3 \mu \mathrm{g}), 0.03 \mu \mathrm{g}$ of phosphodiesterase in $10 \mu \mathrm{l}$ in $10 \mathrm{mM}$ Tris- $\mathrm{HCl} \mathrm{pH} 8$ and $5 \mathrm{mM} \mathrm{MgCl}_{2}$ were incubated at $30^{\circ} \mathrm{C}$ for $1 \mathrm{~h}$. The snake venom phosphodiesterase (SVP) was dissolved in $20 \mathrm{mM}$ Tris- $\mathrm{HCl}(\mathrm{pH} 8)$ at a concentration of $1 \mu \mathrm{g} . \mu \mathrm{l}^{-1}$.

\subsection{Modelling the Structure of A. brasilense glutamine synthetase}

Structural prediction was performed using the Swiss-model server (Waterhouse et al., 2018). The Pymol program (The PyMOL Molecular Graphics System, Version
2.0 Schrödinger, LLC) was used to compare wild-type GS with the mutant P347L-GS.

\section{Results}

\subsection{Purification of glutamine synthetase}

GS was purified from E. coli BL21 by affinity chromatography. SDS-PAGE electrophoresis of the purified fraction showed a band of $\approx 60 \mathrm{kDa}$ (Supplementary Material - Figure S1 and Table S2). The wild-type GS was more than 90\% homogeneous while the P347L-GS was about $80 \%$ homogeneous. The concentrations of wild-type GS obtained were typically $1 \mu \mathrm{g} . \mu \mathrm{l}^{-1}$ while those of P347L-GS were considerably less $\left(0.1 \mu \mathrm{g} . \mu \mathrm{l}^{-1}\right)$.

\subsection{Identification of GS by mass-spectroscopy (MALDI- TOF)}

MALDI-TOF mass-spectroscopy confirmed that the purified proteins were GS of $A$. brasilense (see Table 1). Further proof that the purified proteins was indeed GS, came from western blot analyses (data not shown) which also allowed the separation of the unmodified and adenylylated subunits. An AMP group changes the rate of migration in electrophoreses gels, causing the band to migrate more slowly than non-adenylylated form (Bender and Streicher, 1979), for this reason, a double-band pattern of GS was visible on the SDS-PAGE gels.

\subsection{Assay of transferase activity}

GS transfers the glutamyl radical from L-glutamine to hydroxylamine producing $\gamma$-glutamyl-hydroxamate. Depending on the assay conditions used either the non-adenylylated form is active and catalyzes the transfer (in the presence of low $\mathrm{Mn}^{2+}$ and high $\mathrm{Mg}^{2+}$ ) or both non-adenylylated and adenylylated forms are active (presence of low $\mathrm{Mn}^{2+}$ and absence of $\mathrm{Mg}^{2+}$ ) (Bender et al., 1977). The assay used here determines the fraction of physiologically active (non-adenylylated) GS. Since the two GS forms have different optimum pHs, the reaction was carried out at the iso-active point ( $\mathrm{pH} 7.66$ ) (Machado et al., 1991).

The wild-type GS had high total activity $\left(+\mathrm{Mg}^{2+}\right)$ and low non-adenylylated activity, suggesting that the purified enzyme was heavily adenylylated (see Figure 1A and B). This was expected since the growth medium used to cultivate the overproducing strain rich in nitrogen source. In contrast, P347L-GS had very little activity under both conditions (1,000 times lower than wild-type GS for total activity), suggesting that the P347L mutation drastically affects enzyme activity.

Snake-venom phosphodiesterase (SVP) catalyses the removal of the AMP moiety from GS. When added to

Table 1. Proteins identified by MALDI-TOF mass spectroscopy.

\begin{tabular}{cccccc}
\hline Sample & Protein identified & Mascot MOWSE Score & M.W. (kDa) & \# Peptides identified & Coverage \\
\hline Wild-type GS & Glutamine synthetase & 131 & 52.3 & 12 & $38 \%$ \\
P347L-GS & Glutamine synthetase & 141 & 52.3 & 13 & $33 \%$ \\
\hline
\end{tabular}

${ }^{*}$ Molecular weight. 

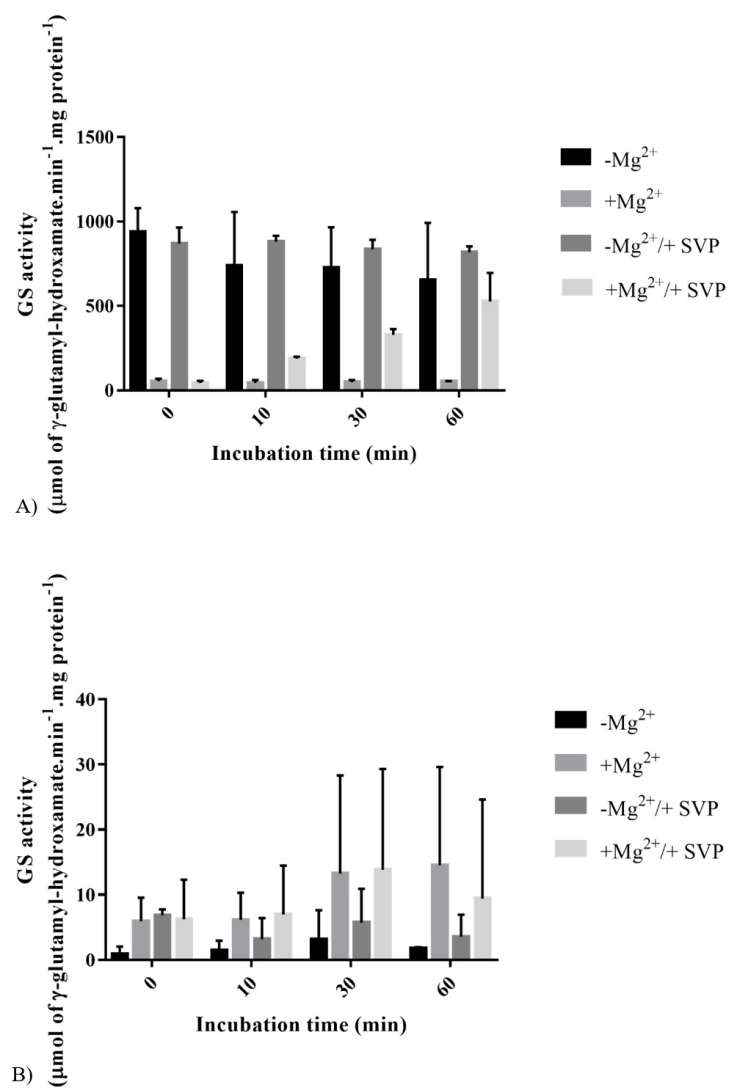

Figure 1. Transferase activity of glutamine synthetase. (A) Transferase activity of wild-type glutamine synthetase in the absence and presence of magnesium as well as with snake venom phosphodiesterase treatment; (B) Transferase activity of P347L glutamine synthetase in the absence and presence of magnesium, and with snake venom phosphodiesterase treatment. The activity of GS is expressed in $\mu \mathrm{mol} \gamma$-glutamyl-hydroxamate. $\mathrm{min}^{-1}$.mg protein $^{-1}$, given that the absorbance of $530 \mathrm{~nm}$ of $1 \mu \mathrm{mol} \gamma$-glutamylhydroxamate was 0.054 . The total activity was determined in the absence of $\mathrm{Mg}^{2+}\left(-\mathrm{Mg}^{2+}\right)$ and the non-adenylylated (active) fraction was determined in the presence of $60 \mathrm{mM} \mathrm{Mg}^{2+}\left(+\mathrm{Mg}^{2+}\right)$. Samples were incubated at $30^{\circ} \mathrm{C}$ for $0,10,30$ and $60 \mathrm{~min}$ before measuring activity. SVP-treated GS samples (+ SVP) were incubated with snake venom phosphodiesterase. GS activity reactions contained $3 \mu \mathrm{g}$ of protein. purified GS (in the presence of $\mathrm{Mg}^{2+}$ ), transferase activity was restored in full, confirming that the purified GS was heavily adenylylated (see Figure 1A). Again, P347L-GS behaved differently - treatment with phosphodiesterase did not alter its activity in under either condition (see Figure 1B).

\subsection{Western blot analyses}

Western blot analyses were also performed before and after digestion with SVP. Wild type GS responded to the treatment (see Figure 2A). Initially the protein was fully adenylylated (one slowly migrating band) but with time the protein lost adenylyl residues as judged by the concomitant appearance of faster migrating band. At the same time, its enzyme activity increased (Figure 1A). In contrast, treatment of P347L-GS with SVP (see Figure 2B) did not affect the protein migration rate nor its activity (see Figure 1B).

\subsection{Structural prediction}

Structural models for A. brasilense GS and the P347L variant were generated using the Swiss-model server org (Waterhouse et al., 2018) with crystal structure of the Salmonella typhimurium GS (Gill and Eisenberg, 2001) and analyzed using the Pymol program (see Figure 3A). Estimation of the quality of the predicted model using the Global Model Quality Estimation (GMQE) was 0.82 for the wild-type GS and 0.81 for P347L-GS. The Root Mean Square Deviation (RMDS) for the alignment of the structural models was 1.296 Angstroms ( $($ ), with all-atom (no outlier rejection) and without superposition. This comparison revealed that the variant P347L most probably affects the secondary structure of the protein at amino acids $352(\mathrm{P})$, $353(\mathrm{~K})$, and $354(\mathrm{G})$. In P347L-GS, this region forms an alpha-helix that is absent from the wild type GS (see Figure 3B). Amino acid 354 interacts in a polar fashion with $351(\mathrm{~S})$, and $356(\mathrm{R})$ in both forms of GS. Another difference possibly caused by the predicted structure of the three amino acids (352-354) is in the position of arginine 356. Overlap of the two structure models showed a difference in the position of this residue of $0.8 \AA$.

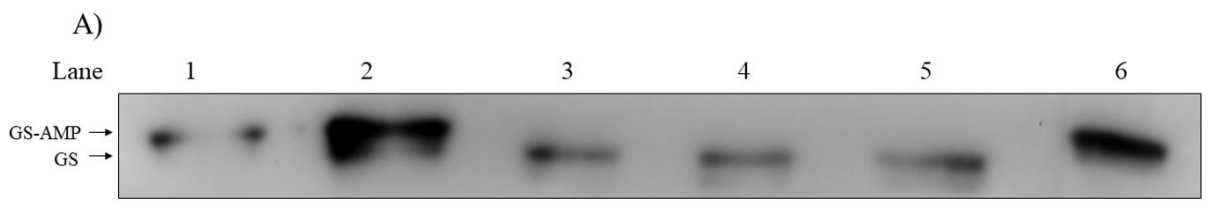

B)

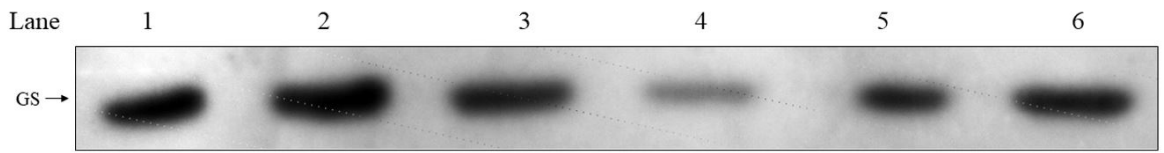

Figure 2. Western blot assays of glutamine synthetase after treatment with snake venom phosphodiesterase. Samples ( $\sim 0.3 \mu \mathrm{g}$ GS protein) were separated by SDS-PAGE followed by Western blotting with an anti-GS antibody. A) Wild-type glutamine synthetase; B) P347L glutamine synthetase. Lane 1: GS after 0 min of incubation at $30^{\circ} \mathrm{C}$ without any treatment; lanes 2 to 5 : GS after $0,10,30$ and 60 min incubation at $30^{\circ} \mathrm{C}$ with snake venom phosphodiesterase. Lane 6: GS after 60 min incubation at $30{ }^{\circ} \mathrm{C}$ without treatment. 
A)

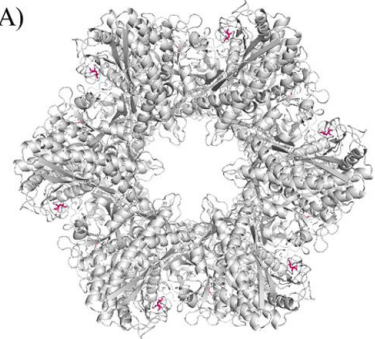

B)

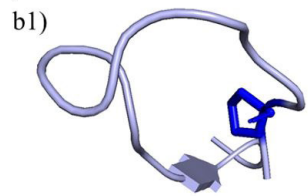

b2)

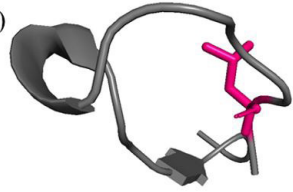

b3)

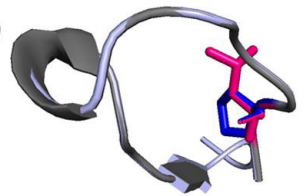

Figure 3. Prediction of the structure of glutamine synthetase from the mutant P347L. (A) Prediction of the P347L-GS structure. The amino acid marked in pink corresponds to leucine in strain HM053; (B) b1) Prediction structure of wild-type GS from amino acid 346 to 361. b2) Prediction structure of P347L-GS from amino acid 346 to 361. b3) Alignment of prediction structures of wildtype GS and P347L GS from amino acid 346 to 361. The amino acid marked in blue corresponds to the proline that is mutated in strain HM053. The amino acid marked in pink is leucine that replaced proline in the mutated amino acid in strain HM053.

\section{Discussion}

Due to its higher solubility, much larger amounts of purified wild type GS were obtained than was the case for P347L-GS. Visual comparisons of SDS-PAGE gels of protein extracts made from cultures induced for $18 \mathrm{~h}$ at $16^{\circ} \mathrm{C}$, suggest that wild-type GS was $\approx 50 \%$ soluble, whereas the mutant was almost completely insoluble. Since the purification method used was for soluble proteins, this would explain the difference in the quantities and qualities of proteins obtained.

Our results are in perfect agreement with previous findings. Machado et al. (1991) worked with the A. brasilense strain HM053 and tested GS activity in vivo under three conditions with cells cultured in minimal medium containing $5 \mathrm{mM}$ glutamate, $2 \mathrm{mM} \mathrm{NH}_{4}^{+}$or $20 \mathrm{mM} \mathrm{NH}_{4}^{+}$ as nitrogen source. Under these conditions, the wild-type strain showed GS activity as between six and fifteen times more active than the GS detected in the HM053 strain. Similar experiments were also performed by Vitorino et al. (2001), who confirmed the higher activity of wild-type GS.

Machado et al. (1991) neither used purified proteins nor knew exactly how much enzyme was present in the assays. Our work with purified GS proved that the specific activity of the P347L-GS present in the HM053 strain was in fact much lower. The low GS activity is likely to restrict $\mathrm{NH}_{4}{ }^{+}$assimilation and glutamine production in the HM053 strain thereby resulting in Nif ${ }^{C}$ phenotype. The low GS activity would result in low intracellular L-glutamine levels in the HM053 strain even when high levels of $\mathrm{NH}_{4}^{+}$levels are present in the culture medium. The reduction in the intracellular glutamine levels would affect the nitrogen sensory cascade in such way that GlnD would maintain the uridylylation of GlnB despite the presence of ammonium in the medium. Uridylylated GlnB activates the NifA protein (Sotomaior et al., 2012) thereby allowing the transcription of the genes for nitrogen fixation (nif) (Pedrosa and Yates, 1984). Under nitrogen-fixing conditions, the low GS activity of HM053 reduces the ability to assimilate the $\mathrm{NH}_{4}^{+}$ produced by nitrogenase thereby facilitating ammonia release by diffusion to the cell membrane to the culture medium (Santos et al., 2017).

Snake-venom phosphodiesterase was able to de-adenylylate the wild type GS (Johansson and Gest, 1977). The P347L-GS variant showed a different behaviour upon treatment with SVP. P347L-GS does not appear to be adenylylated in vivo. Western blotting confirmed that purified P347L-GS was not adenylylated. Somehow, the P347L change of HM053 prevents GS adenylylation by the ATase while reducing the activity of the non-adenylylated form (Machado et al., 1991; Santos et al., 2017). Modelling of the P347L-GS structure and comparison with the wild type $A$. brasilense GS did not reveal remarkable structural differences, except for the secondary structure of the region between the residues 352-354 and a 0.8 A shift in the position of arginine 356 . This result suggests that the point mutation is not affecting directly the active sites of GS. On the other hand, the arginine residue at position 356 does a polar interaction with histidine at position 272 (homologous to H-271 in S. typhimurium (Castellen et al., 2009), which coordinates the $\alpha$-phosphate group of ADP/AMPPMP and E-129 (Liaw et al., 1994b). The shift in R-356 position in GS-P347L changes slightly the bond length and bond angle with $\mathrm{H}-272$, which may affect indirectly the active site. Glutamate at position 129 (homologous to E-131 in A. brasilense (Castellen et al., 2009) does hydrogen bonds with $\mathrm{H}-271$, and coordinates the $\mathrm{n} 2$ ion (Liaw and Eisenberg, 1994a). GS contains two divalent cation sites (n1 and n2) and one monovalent cation site at the subunit interface. Ions that occupy these three ion sites are needed for GS activity. The $\mathrm{n} 1$ metal ion stabilizes the enzyme in the active and, along with $\mathrm{n} 2$, participates in the binding of the negatively charged substrates, glutamate and ATP, and in the phosphoryl transfer from ATP to glutamate, and then the glutamyl transfer from $\gamma$-glutamyl phosphate to ammonia (Ginsburg and Stadtman, 1973; Liaw et al., 1993a, b; Liaw et al., 1994b).

The change P347L also seems to be affecting the structural stability of GS as judged by the reduced solubility 
of the mutant form and absence of adenylylation. However, we could not observe in our model changes that could account for these effects.

In summary we demonstrated that the properties of the mutant form of GS in strain HM053 can explain the constitutive expression of nitrogenase and ammonium excretion, and that modulation of GS activity in nitrogen-fixing bacteria can decouple the tight control of nitrogenase expression and activity allowing excretion of ammonium.

\section{Acknowledgements}

This work was supported by National Institute of Science and Technology on Biological Nitrogen Fixation (INCT/CNPq) and Fundação Araucária/ UK - Brazil Joint Centre for Nitrogen Fixation Centre - Newton Fund. We thank William Broughton for critical reading of the manuscript.

\section{References}

ANTONYUK, L.P., 2007. Glutamine Synthetase of the Rhizobacterium Azospirillum brasilense: Specific Features of Catalysis and Regulation. Applied Biochemistry and Microbiology, vol. 43, no. 3, pp. 244-249. http://dx.doi.org/10.1134/S0003683807030039.

ARAÚJO, L.M., HUERGO, L.F., INVITTI, A.L., GIMENES, C.I., BONATTO, A.C., MONTEIRO, R.A., SOUZA, E.M., PEDROSA, F.O. and CHUBATSU, L.S., 2008. Different responses of the GlnB and $G \ln Z$ proteins upon in vitro uridylylation by the Azospirillum brasilense GlnD protein. Brazilian Journal of Medical and Biological Research, vol. 41, no. 4, pp. 289-294. http://dx.doi.org/10.1590/S0100-879X2008000400006. PMid:18392451.

ASSOCIAÇÃO NACIONAL DOS PRODUTORES E IMPORTADORES DE INOCULANTES - ANPII [online], 2018 [viewed 10 March 2020]. Available from: http://www.anpii.org.br/estatisticas.

BASHAN, Y. and HOLGUIN, G., 1997. Azospirillum-plant relationships: environmental and physiological advances (1990-1996). Canadian Journal of Microbiology, vol. 43, no. 2, pp. 103-121. http://dx.doi. org/10.1139/m97-015.

BENDER, R.A. and STREICHER, S.L., 1979. Glutamine synthetase regulation, adenylylation state, and strain specificity analyzed by polyacrylamide gel electrophoresis. Journal of Bacteriology, vol. 137, no. 2, pp. 1000-1007. PMid: 33958.

BENDER, R.A., JANSEN, K.A., RESNICK, A.D., BLUMENBERG, M., FOOR, F. and MAGASANIK, B., 1977. Biochemical parameters of glutamine synthetase from Klebsiella aerogenes. Journal of Bacteriology, vol. 129, no. 2, pp. 1001-1009. PMid: 14104.

BESPALOVA, L.A., KORSHUNOVA, V.E., ANTONYUK, L.P. and IGNATOV, V.V., 1994. Isolation, purification and some kinetic properties of moderately adenylylated glutamine synthetase from Azospirillum brasilense Sp 245. Biochemistry, vol. 59, pp. 41-45.

BRADFORD, M., 1976. A rapid and sensitive method for the quantitation of microgram quantities of protein utilizing the principle of proteindye binding. Analytical Biochemistry, vol. 72, no. 1-2, pp. 248-254. http://dx.doi.org/10.1016/0003-2697(76)90527-3. PMid:942051.

CAMILIOS-NETO, D., BONATO, P., WASSEM, R., TADRA-SFEIR, M.Z., BRUSAMARELLO-SANTOS, L.C., VALDAMERI, G., DONATTI, L., FAORO, H., WEISS, V.A., CHUBATSU, L.S., PEDROSA, F.O. and SOUZA, E.M., 2014. Dual RNA-seq transcriptional analysis of wheat roots colonized by Azospirillum brasilense reveals up-regulation of nutrient acquisition and cell cycle genes. BMC Genomics, vol. 15, no. 1, pp. 378. http://dx.doi.org/10.1186/1471-2164-15-378. PMid:24886190.
CASTELLEN, P., WASSEN, R., MONTEIRO, R.A., CRUZ, L.M., STEFFENS, M.B.R., CHUBATSU, L.S., SOUZA, E.M. and PEDROSA, F.O., 2009. Structural organization of the glnBA region of the Azospirillum brasilense genome. European Journal of Soil Biology, vol. 45, no. 1, pp. 100-105. http://dx.doi.org/10.1016/j.ejsobi.2008.09.010.

DE ZAMAROCZY, M., PAQUELIN, A., PELTRE, G., FORCHHAMMER, K. and ELMERICH, C., 1996. Coexistence of two structurally similar but functionally different PII proteins in Azospirillum brasilense. Journal of Bacteriology, vol. 178, no. 14, pp. 4143-4149. http://dx.doi. org/10.1128/JB.178.14.4143-4149.1996. PMid:8763942.

DIXON, R. and KAHN, D., 2004. Genetic regulation of biological nitrogen fixation. Nature Reviews Microbiology, vol. 2, pp. 621-631. https:// doi.org/10.1038/nrmicro954.

DOBBELAERE, S., CROONENBORGHS, A., THYS, A., PTACEK, D., VANDERLEYDEN, J., DUTTO, P., LABANDERA-GONZALEZ, C., CABALLERO-MELLADO, J., AGUIRRE, J.F., KAPULNIK, Y., BRENER, S., BURDMAN, S., KADOURI, D., SARIG, S. and OKON, Y., 2001. Response of agronomically important crops to inoculation with Azospirillum. Australian Journal of Plant Physiology, vol. 28, pp. 871-879. http:// dx.doi.org/10.1071/PP01074.

GILL, H.S. and EISENBERG, D., 2001. The crystal structure of phosphinothricin in the active site of glutamine synthetase illuminates the mechanism of enzymatic inhibition. Biochemistry, vol. 40, no. 7, pp. 1903-1912. http://dx.doi.org/10.1021/bi002438h. PMid:11329256.

GINSBURG, A. and STADTMAN, E.R., 1973. Regulation of glutamine synthetase in Escherichia coli. In: S. PRUSINER and E. R. STADTMAN, eds. The enzymes of glutamine metabolism. New York: Academic Press, pp. 9-43.

HARTMANN, A., FU, H. and BURRIS, R.H., 1986. Regulation of nitrogenase activity by ammonium chloride in Azospirillum spp. Journal of Bacteriology, vol. 165, no. 3, pp. 864-870. http://dx.doi.org/10.1128/ JB.165.3.864-870.1986. PMid:3081492.

HAUER, V., 2012. Sequenciamento do gene glnA das estirpes mutantes HM14, HM26, HM053 e HM210 de Azospirillum brasilense. Curitiba: Universidade Federal do Paraná, 48 p. Monografia de graduação em Ciências Biológicas.

HUERGO, L., SOUZA, E., ARAUJO, M., PEDROSA, F.O., CHUBATSU, L.S., STEFFENS, M.B. and MERRICK, M., 2006. ADP-ribosylation of dinitrogenase reductase in Azospirillum brasilense is regulated by AmtB-dependent membrane sequestration of DraG. Molecular Microbiology, vol.59, no. 1, pp. 326-337. http://dx.doi.org/10.1111/ j.1365-2958.2005.04944.X. PMid:16359338.

HUERGO, L.F., SOUZA, E.M., STEFFENS, M.B.R., YATES, G., PEDROSA, F.O. and CHUBATSU, L.S., 2003. Regulation of $g \ln B$ gene promoter expression in Azospirillum brasilense by the NtrC protein. FEMS Microbiology Letters, vol. 223, no. 1, pp. 33-40. http://dx.doi. org/10.1016/S0378-1097(03)00346-X. PMid:12798997.

HUNGRIA, M., CAMPO, R.J., SOUZA, E.M. and PEDROSA, F.O., 2010. Inoculation with selected strains of Azospirillum brasilense and A. lipoferum improves yields of maize and wheat in Brazil. Plant and Soil, vol. 331, no. 1-2, pp. 413-425. http://dx.doi.org/10.1007/ s11104-009-0262-0.

ISHIDA, M.L., ASSUMPÇÃO, M.C., MACHADO, H.B., BENELLI, E.M., SOUZA, E.M. and PEDROSA, F.O., 2002. Identification and characterization of the two-component NtrY/NtrX regulatory system in Azospirillum brasilense. Brazilian Journal of Medical and Biological Research, vol. 35, no. 6, pp. 651-661. http://dx.doi.org/10.1590/S0100879X2002000600004. PMid:12045829.

JOHANSSON, B.C. and GEST, H., 1977. Adenylylation/deadenylylation control of the glutamine synthetase of Rhodopseudomonas capsulata. European Journal of Biochemistry, vol. 81, no. 2, pp. 365-371. http://dx.doi.org/10.1111/j.1432-1033.1977.tb11960.x. PMid:23287.

LAWLORDAVID, W., 2002. Carbon and nitrogen assimilation in relation to yield: mechanisms are the key to understanding production systems. Journal of Experimental Botany, vol. 370, no. 53, pp. 773787. http://dx.doi.org/10.1093/jexbot/53.370.773. PMid:11912221. 
LEIGH,J.A. and DODSWORTH,J.A., 2007. Nitrogen regulation in bacteria and Archaea. Annual Review of Microbiology, vol. 61, no. 1, pp. 349377. http://dx.doi.org/10.1146/annurev.micro.61.080706.093409. PMid: 17506680 .

LIAW, S. and EISENBERG, D., 1994a. Structural model for the reaction mechanism of glutamine synthetase, based on five crystal structures of enzyme-substrate. Biochemistry, vol.33, no. 3, pp.675-681. http:// dx.doi.org/10.1021/bi00169a007. PMid:7904828.

LIAW, S., JUN, G. and EISENBERG, D., 1994b. Interactions of nucleotides with fully unadenylylated glutamine synthetase from Salmonella typhimurium. Biochemistry, vol.33, no.37, pp. 11184-11188. http:// dx.doi.org/10.1021/bi00203a014. PMid:7727369.

LIAW, S., PAN, C. and EISENBERG, D., 1993a. Feedback inhibition of fully unadenylylated glutamine synthetase from Salmonella typhimurium by glycine, alanine, and serine. Proceedings of the National Academy of Sciences of the United States of America, vol. 90, no. 11, pp. 49965000. http://dx.doi.org/10.1073/pnas.90.11.4996. PMid:8099447.

LIAW, S., VILLAFRANCA, J.J. and EISENBERG, D., 1993b. A model for oxidative modification of glutamine synthetase, based on crystal structures of mutant $\mathrm{H} 269 \mathrm{~N}$ and the oxidized enzyme. Biochemistry, vol. 32, no. 31, pp. 7889-8003. http://dx.doi. org/10.1021/bi00082a022. PMid:8102250.

MACHADO, H.B., FUNAYAMA, S., RIGO, S.L.U. and PEDROSA, F.O., 1991. Excretion of ammonium by Azospirillum brasilense mutants resistant to ethylenediamine. Canadian Journal of Microbiology, vol. 37, no. 7, pp. 549-553. http://dx.doi.org/10.1139/m91-092.

MANGUM, J.H., MAGNI, G. and STADTMAN, E.R., 1973. Regulation of glutamine synthetase adenylylation and deadenylylation by the enzymatic uridylylation and deuridylylation of the PII regulatory protein. Archives of Biochemistry and Biophysics, vol. 158, no. 2 pp. 514-525. http://dx.doi.org/10.1016/0003-9861(73)90543-2. PMid:4150122.

MERRICK, M.J. and EDWARDS, R.A., 1995. Nitrogen control in bacteria. Microbiological Reviews, vol. 59, no. 4, pp. 604-622. http://dx.doi. org/10.1128/MR.59.4.604-622.1995. PMid:8531888.

MOURE, V.R., COSTA, F.F., CRUZ, L.M., PEDROSA, F.O., SOUZA, E.M., LI, X.D., WINKLER, F., and HUERGO, L.F., 2014. Regulation of nitrogenase by reversible Mono-ADP-ribosylation. In: F. KOCH-NOLTE, eds. Endogenous ADP-ribosylation. Current Topics in microbiology and immunology. Cham: Springer, vol. 384, pp. 89-196. http://dx.doi. org/10.1007/82_2014_380.

PANKIEVICZ, V.C.S., DO AMARAL, F.P., SANTOS, K.F.D.N., AGTUCA, B., XU, Y., SCHUELLER, M.J., ARISI, A.C., STEFFENS, M.B., DE SOUZA, E.M., PEDROSA, F.O., STACEY, G. and FERRIERI, R.A., 2015. Robust biological nitrogen fixation in a model grass-bacterial association. The Plant Journal, vol.81, no.6, pp.907-919. http://dx.doi.org/10.1111/ tpj.12777. PMid:25645593.

PEDROSA, F.O. and YATES, M.G., 1984. Regulation of nitrogen fixation (nif) genes of Azospirillum brasilense by nifA and $n$ tr ( $g l n$ ) type gene products. FEMS Microbiology Letters, vol. 23, no. 1, pp. 95-101. http:// dx.doi.org/10.1111/j.1574-6968.1984.tb01042.x.

PIROLA, M.C., MONOPOLI, R., ALIVERTI, A. and ZANETTI, G., 1992. Isolation and characterization of glutamine synthetase from the diazotroph Azospirillum brasilense. The International Journal of Biochemistry, vol. 24, no. 11, pp. 1749-1754. http://dx.doi. org/10.1016/0020-711X(92)90124-J.

SAMBROOK, J., FRITSCH, E.F. and MANIATIS, T., 1989. Molecular cloning: a laboratory manual. 2. ed. New York: Cold Spring Harbor Laboratory Press.

SANTOS, K.F.D.N., MOURE, V.R., HAUER, V., SANTOS, A.R.S., DONATTI, L., GALVÃO, C.W., PEDROSA, F.O., SOUZA, E.M., WASSEM, R. and STEFFENS, M.B.R., 2017. Wheat colonization by an Azospirillum brasilense ammonium-excreting strain reveals upregulation of nitrogenase and superior plant growth promotion. Plant and
Soil, vol. 415, no. 1-2, pp. 245-255. http://dx.doi.org/10.1007/ s11104-016-3140-6.

SHEVCHENKO, A., WILM, M., VORM, O. and MANN, M., 1996. Mass spectrometric sequencing of proteins from silver-stained polyacrylamide gels. Analytical Chemistry, vol. 68, no. 5, pp. 850-858. http://dx.doi.org/10.1021/ac950914h. PMid:8779443.

SOTOMAIOR, P., ARAÚJO, L.M., NISHIKAWA, C.Y., HUERGO, L.F., MONTEIRO, R.A., PEDROSA, F.O., CHUBATSU, L.S. and SOUZA, E.M., 2012. Effect of ATP and 2-oxoglutarate on the in vitro interaction between the NifA GAF domain and the GlnB protein of Azospirillum brasilense. Brazilian Journal of Medical and Biological Research, vol. 45, no. 12, pp. 1135-1140. http://dx.doi.org/10.1590/S0100879X2012007500146. PMid:22983183.

STEENHOUDT, O. and VANDERLEYDEN, J., 2000. Azospirillum, a free-living nitrogen-fixing bacterium closely associated with grasses: genetic, biochemical and ecological aspects. FEMS Microbiology Reviews, vol. 24, no. 4, pp. 487-506. http://dx.doi. org/10.1111/j.1574-6976.2000.tb00552.x. PMid:10978548.

TER STEEGE, M. W., STULEN, I. and MARY, B., 2001. Nitrogen in the environment. In: P.J. LEA and J.-F. MOROT-GAUDRY, eds. Plant nitrogen. Berlin: Springer-Verlag.

VANDOMMELEN, A., KEJJERS, V., WOLLEBRANTS, A. and VANDERLEYDEN, J., 2003. Phenotypic changes resulting from distinct point mutations in the Azospirillum brasilense glnA gene, encoding glutamine synthetase. Applied and Environmental Microbiology, vol. 69, no. 9, pp.5699-5701.http://dx.doi.org/10.1128/AEM.69.9.5699-5701.2003. PMid:12957965.

VAN HEESWIJK, W.C., HOVING, S., MOLENAAR, D., STEGEMAN, B., KAHN, D. and WESTERHOFF, H.V., 1996. An alternative Pll protein in the regulation of glutamine synthetase in Escherechia coli. Molecular Microbiology, vol. 21, no. 1, pp. 133-146. http://dx.doi. org/10.1046/j.1365-2958.1996.6281349.x. PMid:8843440.

VANCE, C., 2001. Symbiotic nitrogen fixation and phosphorus acquisition. Plant nutrition in a world of declining renewable resources. Plant Physiology, vol. 127, no. 2, pp. 391-397. http://dx.doi.org/10.1104/ pp.010331. PMid:11598215.

VITORINO,J.C., STEFFENS, M.B.R., MACHADO, H.B., YATES, M.G., SOUZA, E.M. and PEDROSA, F.O., 2001. Potential roles for the $\ln B$ and $n t r Y X$ genes in Azospirillum brasilense. FEMS Microbiology Letters, vol. 201, no. 2, pp. 199-204. http://dx.doi.org/10.1111/j.1574-6968.2001. tb10757.x. PMid:11470362.

WATERHOUSE, A., BERTONI, M., BIENERT, S., STUDER, G., TAURIELLO, G., GUMIENNY, R., HEER, F.T., DE BEER, T.A.P., REMPFER, C., BORDOLI, L., LEPORE, R. and SCHWEDE, T., 2018. SWISS-MODEL: homology modelling of protein structures and complexes. Nucleic Acids Research, vol. 46, no. 1, pp. 296-303. http://dx.doi.org/10.1093/ nar/gky427. PMid:29788355.

WESTBY, C.A., ENDERLIN, C.S., STEINBERG, N.A., JOSEPH, C.M. and MEEKS, J.C., 1987. Assimilation of $13 \mathrm{NH}_{4}^{+}$by Azospirillum brasilense grown under nitrogen limitation and excess. Journal of Bacteriology, vol. 169, no. 9, pp. 4211-4214. http://dx.doi. org/10.1128/JB.169.9.4211-4214.1987. PMid:2887545.

WISNIEWSKI-DYÉ, F., BORZIAK, K., KHALSA-MOYERS, G., ALEXANDRE, G., SUKHARNIKOV, L.O., WUICHET, K., HURST, G.B., HAYES MCDONALD, W., ROBERTSON, J.S., BARBE, V., CALTEAU, A., ROUY, Z., MANGENOT, S., PRIGENT-COMBARET, C., NORMAND, P., BOYER, M., SIGUIER, P., DESSAUX, Y., ELMERICH, C., CONDEMINE, G., KRISHNEN, G., KENNEDY, I., PATERSON, A.H., GONZÁLEZ, V., MAVINGUI, P. and ZHULIN, I.B., 2011. Azospirillum genomes reveal transition of bacteria from aquatic to terrestrial environments. PLoS Genet, vol. 7, no. 12, e1002430. https://doi. org/10.1371/journal.pgen.1002430. 
Ghenov, F. et al.

\section{Supplementary Material}

Supplementary material accompanies this paper.

Figure S1. 10\% SDS-PAGE gel of purified glutamine synthetase.

Table S1. Table of primers used to amplified the glnA genes of A. brasilense FP2 (wild type) and HM053.

Table S2. Table of purification of glutamine synthetase.

This material is available as part of the online article from http://www.scielo.br/bjb 